\title{
INDUSTRIALIZAÇÃO COMO AGENTE TRANSFORMADOR DA QUALIDADE DE VIDA
}

\author{
Rafael da Silva Tavares Martins ${ }^{1}$ \\ Deyvison Roberto Nascimento ${ }^{2}$
}

Resumo: O trabalho a seguir tem como propósito discutir os benefícios socioeconômicos originários em um processo de industrialização numa determinada localidade. Através de dados coletados em órgãos governamentais e federações será feito uma análise comparativa do desenvolvimento socioeconômico em dois municípios do estado do Rio de Janeiro, quais sejam, Porto Real e Quatis levando em consideração seus graus distintos de industrialização, a fim de corroborar com a ideia que a indústria promove o desenvolvimento. A disposição do trabalho se dará com uma introdução, onde será abordado com mais clareza o tema proposto. Logo após, a metodologia a ser utilizada na pesquisa e que tem como critério uma análise comparativa de dados como IDH e IFDM. Em seguida, será tratada a discussão do trabalho, e para melhor compreensão do texto haverá uma breve diferenciação entre crescimento e desenvolvimento, concomitante as análises socioeconômicas. Para por fim, a conclusão, onde serão discutidos os desfechos das análises.

Palavras-chave: Industrialização; Crescimento; Desenvolvimento.

\footnotetext{
${ }^{1}$ Administração/Centro Universitário Barra Mansa, Brasil. E-mail: rafaqts@gmail.com.

2 Administração/Centro Universitário Barra Mansa, Brasil. E-mail: prof.deyvison.nascimento@gmail.com.
} 